\title{
The choice of the anchoring protein influences the interaction of recombinant Bacillus spores with the immune system
}

\author{
Aurelia Piekarska1, Paulina Pełka1', Grażyna Peszyńska-Sularz², Alessandro Negri', \\ Krzysztof Hinc ${ }^{3}$, Michał Obuchowski and Adam Iwanicki ${ }^{3 凶}$
}

'Department of Medical Biotechnology, Intercollegiate Faculty of Biotechnology UG-MUG, University of Gdańsk, Gdańsk, Poland; 2 Tri-City Animal Laboratory, Medical University of Gdańsk, Gdańsk, Poland; ${ }^{3}$ Department of Medical Biotechnology, Intercollegiate Faculty of Biotechnology UG-MUG, Medical University of Gdańsk, Gdańsk, Poland

The technology of display of heterologous proteins on the surface of Bacillus subtilis spores enables use of these structures as carriers of antigens for mucosal vaccination. Currently, there are no technical possibilities to predict whether a designed fusion will be efficiently displayed on the spore surface and how such recombinant spores will interact with cells of the immune system. In this study, we compared four variants of $B$. subtilis spores presenting a fragment of a FliD protein from Clostridium difficile in fusion with $\operatorname{Cot} B, \operatorname{Cot} C$, $\operatorname{Cot} G$ or CotZ spore coat proteins. We show that these spores promote their own phagocytosis and activate both, the J774 macrophages and JAWSII dendritic cells of murine cell lines. Moreover, we used these spores for mucosal immunization of mice. We conclude that the observed effects vary with the type of displayed FliD-spore coat protein fusion and seem to be mostly independent of its abundance and localization in the spore coat structure.

Key words: Bacillus subtilis; spore display; APCs; FliD; Clostridium difficile; immune response

Received: 25 September, 2016; revised: 12 October, 2016; accepted: 17 October, 2016; available on-line: 12 April, 2017

e-mail: aiwanicki@gumed.edu.pl

Abbreviations: APC, antigen-presenting cell; TLR, Toll-like receptor

\section{INTRODUCTION}

The use of recombinant Bacillus subtilis spores as carriers of antigens in mucosal vaccines is currently in the focus of interest of different research groups. The unique properties of spores make them very attractive candidates for such applications. The resistance of spores to extreme conditions allows them to easily pass the barrier of the stomach environment, which is the crucial step for efficient delivery of antigens into the further parts of the gastrointestinal tract. It is worth to mention that B. subtilis spores are ubiquitous (Abhyankar et al., 2014) and can be found not only in the soil, but also in the gut of humans and animals (Fakhry et al., 2008; Hong et al., 2009). They are also used as probiotics, which clearly suggests lack of side effects associated with their ingestion (Cutting, 2011).

The extreme resistance of spores is a direct result of their structure. A highly dehydrated spore core containing nucleoid saturated with small acid-soluble proteins (SASPs) is surrounded by a thick layer of cortex. The protective layer surrounding the spore, the coat, ensures its resistance to chemical, physical, as well as enzymatic agents. The coat is a proteinaceous structure in which two distinct layers can be distinguished, the inner and the outer coat. The outermost layer surrounding the spore is called the crust (McKenney et al., 2013).

The technology of displaying heterologous proteins on the surface of spores has been devised at the beginning of the last decade (Isticato et al., 2001). The basis of this technology is to introduce a gene fusion of a gene encoding a protein of interest with one of the spore coat genes into the chromosome of B. subtilis (Ricca et al., 2014). Then, spores formed in a natural process of sporulation will present the fusion protein on their surface. Since the initial report, there have been numerous successful attempts to present different proteins on the surface of spores (reviewed in Isticato et al., 2014). One of the most interesting aspects is the possibility to use spores as carriers of antigens in mucosal vaccines. Several studies had shown that orally-administered recombinant $B$. subtilis spores can elicit a protective immune response against infections caused by such pathogens as Clostridium perfringens (Hoang et al., 2008), Clostridium difficile (Permpoonpattana et al., 2011), Clostridium tetani (Duc le et al., 2003), or the white spot syndrome virus (Valdez et al., 2014). In most of such studies, three spore coat proteins, CotB, CotC and CotG, have been used for anchoring of heterologous proteins. It has been also shown that the CotZ and CgeA crust proteins can be also useful for spore display technology (Hinc et al., 2014; Iwanicki et al., 2014).

Despite the growing interest in application of recombinant spores as carriers of antigens, currently there are no technical possibilities to predict whether the designed fusion will be efficiently displayed on the surface of the spore. To facilitate such research, our group has recently designed a set of universal vectors for spore surface display (Iwanicki et al., 2014). Nevertheless, the only way to verify the presentation of a heterologous protein on the spore surface is still by the experimental approach.

In our recent work, we have constructed a series of recombinant $B$. subtilis spores displaying a fragment of a flagellar cap protein FliD from Clostridium difficile (Negri et al., 2013). Since in that study FliD was anchored to the $\operatorname{Cot} B, \operatorname{Cot} C$ and $\operatorname{Cot} G$ spore coat proteins, as well as, to the CotZ spore crust protein, we have obtained a panel of recombinant spores displaying the same antigen but in fusion with different carrier proteins. This enabled us to conduct research presented here, where we investigate how the use of different anchoring proteins influences the interaction of recombinant spores with cells of the innate immune system. FliD is known to be a strongly immunogenic protein (Péchiné et al., 2005; Sánchez-Hurtado et al., 2008) and was shown to be involved 
in adhesion of $C$. difficile to epithelial cells (Tasteyre et al., 2001). As the recognition of antigen and its phagocytosis is the very first step in the eliciting of the immune response, in the study presented here we tested how different FliD-presenting spores stimulated the phagocytic activity and activated the murine macrophages and dendritic cells. Moreover, we wanted to check the immune response in mice that were mucosally immunized with these spores.

\section{MATERIALS AND METHODS}

Ethics statement. This study was carried out in strict accordance with the recommendations of the institutional and national guidelines for animal care and use. The protocol was approved by the Committee on the Ethics of Animal Experiments of the Medical University of Gdańsk (Permit Number: 4/2010). All surgeries were performed under isoflurane anesthesia, and all possible efforts were made to minimize the animal suffering. A total of 35 mice were used in this study.

Bacterial strains. Bacterial strains used in this study are listed in Table 1.

Table 1. List of $B$. subtilis strains

\begin{tabular}{|c|c|c|}
\hline Strain & Relevant genotype & Reference \\
\hline 168 & $\operatorname{trpC2}$ & $\begin{array}{l}\text { (Anagnostopoulos \& Craw- } \\
\text { ford, 1961) }\end{array}$ \\
\hline BAN01 & amyE::cotB-fliD & (Negri et al., 2013) \\
\hline BAN02 & amyE::cotC-fliD & (Negri et al., 2013) \\
\hline BAN03 & amyE::cotG-fliD & (Negri et al., 2013) \\
\hline BAN04 & amyE:::cotZ-fliD & (Negri et al., 2013) \\
\hline
\end{tabular}

Cell lines and propagation. The murine monocytic macrophage cell line J774 and the dendritic cells cell line JAWSII were purchased from the American Tissue and Cell Collection (ATCC). The J774 cells were propagated in DMEM complete medium supplemented with $10 \%$ heat inactivated FBS, $100 \mathrm{IU} / \mathrm{ml}$ penicillin, and $100 \mathrm{mg} /$ $\mathrm{ml}$ streptomycin, at $37^{\circ} \mathrm{C}$ in $5 \% \mathrm{CO}_{2}$, at $95 \%$ humidity. Cells were subcultured every 3 days at the $1: 5$ ratio. The JAWS II cells were propagated in RPMI-1640 medium supplemented with L-glutamine; $25 \mathrm{mM}$ HEPES, 10\% heat inactivated FBS, $100 \mathrm{IU} / \mathrm{ml}$ penicillin and $100 \mathrm{mg} /$ $\mathrm{ml}$ streptomycin, at $37^{\circ} \mathrm{C}$ in $5 \% \mathrm{CO}_{2}$, at $95 \%$ humidity. Cells were subcultured every week at the 1:5 ratio. Cell viability was monitored by Trypan Blue exclusion.

Spore preparation and purification. Sporulation was induced by the exhaustion method in the Difco sporulation medium (DSM, 0.8\% Difco Nutrient Broth; 10\% (w/v) $\mathrm{KCl} ; 1.2 \%$ (w/v) $\mathrm{MgSO}_{4} ; 1 \mathrm{mM} \mathrm{NaOH} ; 1 \mathrm{mM}$ $\mathrm{Ca}\left(\mathrm{NO}_{3}\right)_{2} ; 0.1 \mathrm{mM} \mathrm{MnCl} ; 1 \mu \mathrm{M} \mathrm{FeSO}$ ) as described elsewhere (Nicholson \& Setlow, 1990). Sporulating cultures were harvested $24 \mathrm{~h}$ after the initiation of sporulation. Spore formation was examined under a light microscope. The spores were purified using a lysozyme treatment to break up any residual sporangial cells, followed by washing steps in $1 \mathrm{M} \mathrm{NaCl}, 1 \mathrm{M} \mathrm{KCl}$, and water (each step was repeated twice). In order to eradicate any vegetative cells, after the final suspension in water, the spores were heat-treated at $65^{\circ} \mathrm{C}$ for $1 \mathrm{~h}$. The number of spores in the suspension was determined using the Thoma cell counting chamber. The spores were stored at $-20^{\circ} \mathrm{C}$ for further use.

Germination assay. The spores were heat activated at $80^{\circ} \mathrm{C}$ for $20 \mathrm{~min}$. Next, serial dilutions were prepared, plated onto LB medium (1\% Tryptone, $1 \% \mathrm{NaCl}, 0.5 \%$ yeast extract) solidified with $1.5 \%$ agar, and incubated overnight at $37^{\circ} \mathrm{C}$. The Number of obtained colonies was used for calculation of the germination efficiency.

Phagocytosis assay. The J774 or JAWSII cells were dispensed into 24 -well plates at a density of approximately $5 \times 10^{4}$ cells per well, in complete medium appropriate for a particular cell line. After two days of incubation, B. subtilis spores of the 168 or another appropriate strain were added to monolayers of cells at an m.o.i. of 10 (approx. $5 \times 10^{5}$ spores per well) and phagocytosis was allowed to proceed for $2 \mathrm{~h}$ at $37^{\circ} \mathrm{C}$ in $5 \%$ $\mathrm{CO}_{2}$. Background levels of spores that were physically attached to cells but which did not undergo phagocytosis, were determined by uptake of spores by cells incubated in a medium containing $1 \mu \mathrm{M}$ cytochalasin B (phagocytosis inhibitor) and $2.5 \mu \mathrm{g} / \mathrm{ml}$ gentamicin. After $2 \mathrm{~h}$, the cell monolayers were washed 5 times with sterile PBS. To quantify the total number of intracellular $B$. subtilis spores, the cells were lysed by resuspension in sterile distilled water and serial dilutions of lysate from each well were prepared and plated onto LB medium solidified with $1.5 \%$ agar. To evaluate spore counts, lysates were heated at $85^{\circ} \mathrm{C}$ for $20 \mathrm{~min}$ to kill all heat-sensitive vegetative $B$. subtilis cells, prior to serial dilution and plating. The number of colonies obtained after plating lysates of cytochalasin B-treated cells was subtracted from the number of colonies obtained after plating lysates of cells untreated with cytochalasin $\mathrm{B}$, giving the number of phagocytosed spores.

Activation assays. The activation of J774 and JAWSII cells was assessed by ELISA detecting TNF- $\alpha$ and IL-12, respectively. $1 \times 10^{5}$ of the J774 or JAWSII cells were seeded in 96-well culture cell plates in DMEM complete medium. The cells were stimulated with the 168 spores or spores of another appropriate strain at an m.o.i. of $10\left(1 \times 10^{6}\right.$ spores/well $)$ or only with a medium, at $37^{\circ} \mathrm{C}$ in a $5 \% \mathrm{CO}_{2}$. Supernatants were harvested after $6 \mathrm{~h}$ of incubation. ELISA assay was performed according to the manufacturer's instructions (BD Biosciences). Briefly, microtiter 96-well plates were coated overnight at $4^{\circ} \mathrm{C}$ with anti-mouse TNF- $\alpha$ or IL-12 monoclonal antibodies in a coating buffer. Free binding sites were blocked with the Assay diluent for $1 \mathrm{~h}$ at room temperature. Culture supernatants were tested in triplicates at room temperature for $2 \mathrm{~h}$. Samples were applied using a two-fold dilution series starting with 1:10 dilution in the Assay diluent. Cytokines were detected with a biotinylated anti-mouse TNF- $\alpha$ or IL-12 and streptavidin-horseradish peroxidase conjugate, at room temperature for $1 \mathrm{~h}$. Concentration of TNF- $\alpha$ or IL- 12 was measured by a colorimetric method using BIO-TEK ELx800 ELISA plate reader.

Immunizations. Five groups of seven mice (female, $\mathrm{BALB} / \mathrm{c}, 8$ weeks) were immunized by the intranasal route with suspensions of either spores of the 168 wildtype strain or recombinant spores presenting the FliD fragment. A naive, non-immunized control group was included. Intranasal immunizations were performed with $5 \times 10^{9}$ spores in the volume of $20 \mathrm{ml}$ of water administered once a week for eight weeks (Isticato et al., 2013). Upon completion of the immunization cycle, the animals were sacrificed and blood, spleens, lungs and entire gastrointestinal tracts were collected. 
Indirect ELISA for detection of antigen-specific antibodies. FliD-specific antibodies in saponin extracts of gastrointestinal tracts or lungs, and sera of the immunized animals were detected as previously described (Hinc et al., 2014). Briefly, plates were coated with 100 $\mathrm{ml}$ per well of the specific antigen $(2 \mathrm{mg} / \mathrm{ml}$ in carbonate/bicarbonate buffer) and left at room temperature overnight. Purified FliD protein was used as antigen. After blocking with $0.5 \% \mathrm{BSA}$ in PBS for $1 \mathrm{~h}$ at $37^{\circ} \mathrm{C}$, the samples were applied using a two-fold dilution series starting with a $1 / 20$ dilution in the ELISA diluent buffer $(0.1 \mathrm{M}$ Tris-HCl, pH 7.4, 3\% (w/v) NaCl, 0.5\% (w/v) BSA, 10\% (v/v) sheep serum (Sigma), 0.1\% (v/v) Triton-X-100, 0.05\% (v/v) Tween-20). Every plate carried replicate wells of a negative control (a 1/20 diluted pre-immune serum), and a standard curve prepared with control serum from mice immunized intraperitoneally with the FliD purified protein. Plates were incubated for $2 \mathrm{~h}$ at $37^{\circ} \mathrm{C}$ before addition of anti-mouse AP conjugates (Sigma). The plates were incubated for another hour at $37^{\circ} \mathrm{C}$ and then developed using the pNPP substrate (para-Nitrophenylphosphate; Sigma). Reactions were stopped using $2 \mathrm{M} \mathrm{H}_{2} \mathrm{SO}_{4}$ and absorbance was read at $492 \mathrm{~nm}$. Titers of FliD-specific antibodies were calculated by using a standard curve.

Isolation of splenocytes. The mice were sacrificed and their spleens were isolated as previously described (Hinc et al., 2014). Briefly, the mice were sacrificed and spleens were aseptically removed. The spleens were perfused with RPMI-1640 (supplemented with 10\% heat inactivated fetal calf serum, $25 \mathrm{mM}$ Hepes, $2 \mathrm{mM}$ L-glutamine, $1 \mathrm{mM}$ sodium pyruvate, $100 \mathrm{IU} / \mathrm{ml}$ penicillin and $100 \mathrm{mg} / \mathrm{ml}$ streptomycin) using a $5 \mathrm{ml}$ syringe fitted with $26 \mathrm{G}$ needle to obtain a single cell suspension of splenocytes. The splenocyte suspension was then centrifuged at $300 \times g$ for $15 \mathrm{~min}$. The RBCs were lysed by hypotonic shock using $3 \mathrm{ml}$ of $0.84 \%$ sterile $\mathrm{NH}_{4} \mathrm{Cl}$ or ACK lysis buffer for $5 \mathrm{~min}$. The cells were then washed thrice with RPMI-1640 to remove the lysed RBCs and $\mathrm{NH}_{4} \mathrm{Cl}$.

Activation of splenocytes. Splenocytes $\left(2 \times 10^{5} / \mathrm{ml}\right)$ were cultured in the presence or absence of the FliD antigen for $48 \mathrm{~h}$. Samples of supernatants containing the released cytokines were collected and stored at $-80^{\circ} \mathrm{C}$.

IFN- $\gamma$, IL-4 and IL-17A ELISA assays. The amounts of IFN- $\gamma$, IL-4 and IL-17A-secreting cells were determined by using ELISA kits according to the manufacturer's instructions (R\&D Systems).

Statistical analysis. Differences among the various experimental groups in results of the spore germination, phagocytosis and activation assays were determined by the one-way ANOVA test, followed by Tukey's honest significant difference test for post hoc analysis. In the case of FliD-specific antibodies and cytokines ELISA assays, the obtained results did not follow a normal distribution, as verified by Shapiro-Wilk test of normality, so the differences among the various experimental groups were determined by the Kruskal-Wallis non-parametric test, followed by Dunn's Multiple Comparison Test for post hoc analysis.

\section{RESULTS}

\section{Display of FliD does not influence germination of the recombinant spores}

Our previous study suggested that recombinant B. subtilis spores presenting a fragment of the FliD protein possessed unaltered properties and functionality (Negri et al., 2013). Since the precise assessment of germination efficiency of spores produced by different recombinant strains was crucial for analysis of the results of phagocytosis assays we compared the germination efficiency of all spores used in this study. The efficiency of germination was slightly lower for the recombinant spores, nevertheless these differences, when compared to spores of the wild-type strain, were not statistically significant (Fig. 1).

\section{FliD-presenting spores are phagocytosed with different efficiency}

Before an antigen could be presented to cells of the adaptive immune system, it needs to be phagocytosed and processed by the antigen presenting cells (APCs). Generally, the B. subtilis spores are phagocytosed by cells of the innate immune system with low efficiency, which does not exceed 2.5-3\% (Duc et al., 2004; Ceragioli et al., 2009). Since FliD is a strong immunogenic protein, we wanted to check how the FliD-presenting spores promote their phagocytosis. The efficiency of phagocytosis significantly differed between different recombinant spores presenting the FliD protein (Fig. 2). The overall pattern of phagocytosis efficiency was the same for both, the J774 macrophages and JAWSII dendritic cells. The highest uptake was observed for BAN01 spores (CotBFliD), and in this case the JAWSII cells phagocytosed almost 50\% more spores than the J774 cells. It is also worth noting that the same tendency was observed for spores of the wild-type and BAN03 (CotG-FliD) strains.

\section{The activation of cells of the innate immunity differs} with changes of the carrier protein for FliD

Macrophages and dendritic cells encountering antigens become activated, which can be assessed by measuring the levels of released proinflammatory cytokines. We performed ELISA tests to measure levels of TNF- $\alpha$ released by J774 macrophages and IL-12 by JAWSII dendritic cells, after mixing these cells with the analyzed recombinant spores. Naive cells of both cell lines used in this study did not produce significant levels of the

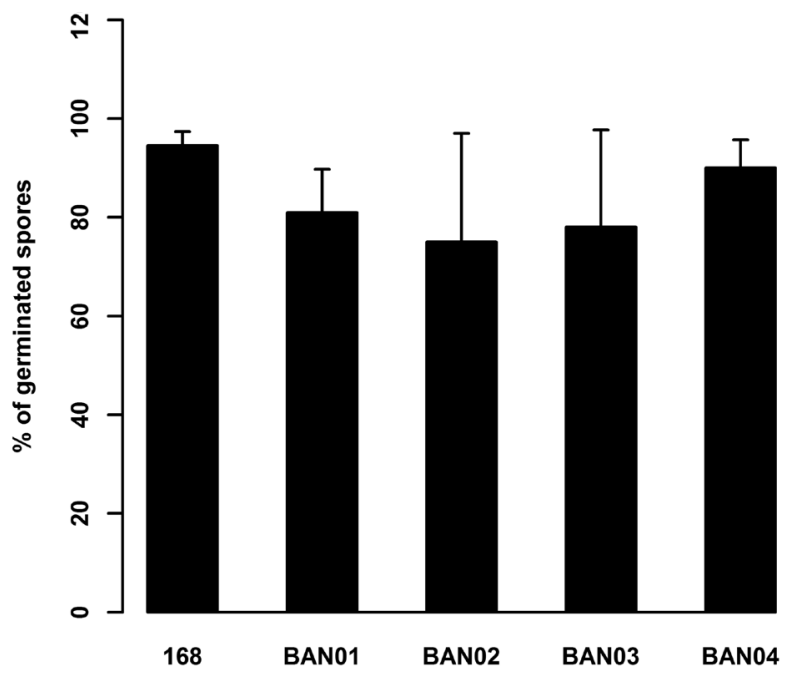

Figure 1. Germination efficiency of recombinant spores.

Spores of strains indicated at the horizontal axis were counted, activated by heat-treatment, and plated onto the solid medium. The number of obtained colonies was used to calculate the germination efficiency. Plot was generated with data obtained from three independent experiments. Error bars indicate standard deviation. 


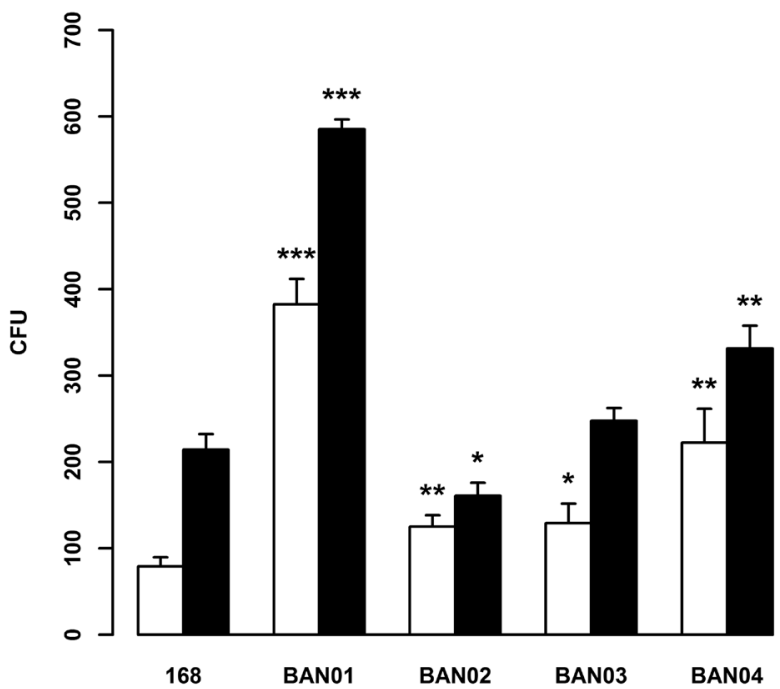

Figure 2. Efficiency of phagocytosis of recombinant spores.

The J774 and JAWSII cells were treated with recombinant spores, as described in the Materials and Method section, and the number of phagocytosed spores was assessed by counting the colonies obtained after plating of cell lysates. Open bars - J774 cells, filled bars - JAWSII cells. Error bars indicate standard deviation. The data are averages from three independent experiments. Statistical significance of results obtained with spores of the analyzed recombinant strains was assessed against data obtained with spores of the 168 wild-type strain for each cell line separately, ${ }^{*} p<0.05,{ }^{* *} p<0.01,{ }^{* * *} p<0.001$.

analyzed cytokines. The highest activation of both types of cells was observed for spores of the BAN02 (CotCFilD) strain (Fig. 3). Spores of the BAN04 (CotZ-FliD) strain were also activating JAWSII cells stronger than the other spores used in this study, which was not observed for the J774 macrophages.

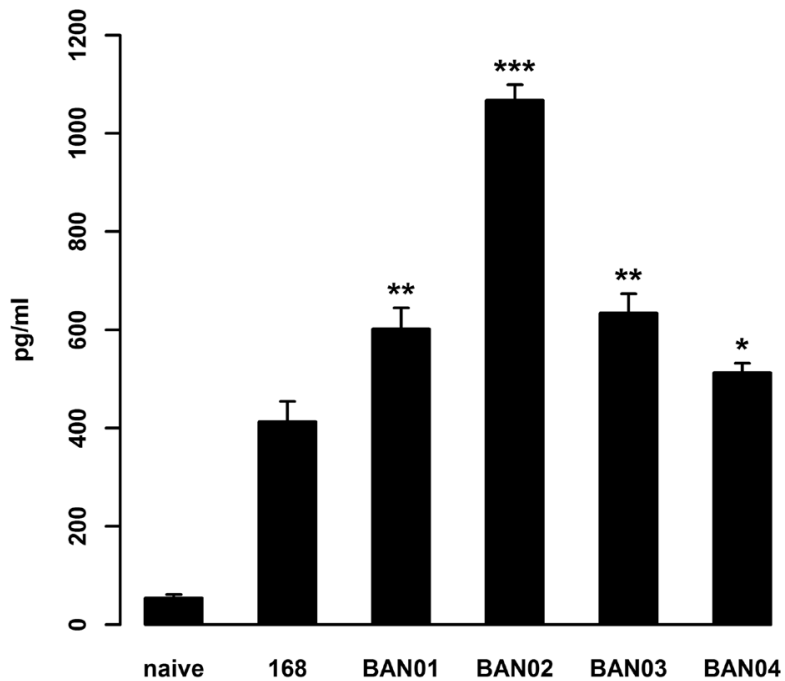

Figure 3. Activation of $\mathrm{J} 774$ cells by recombinant spores as assessed by measurement of the released TNF-a.

The $\mathbf{J 7 7 4}$ cells were treated for $24 \mathrm{~h}$ with spores of strains indicated at the horizontal axis, and the amount of released TNF-a was measured by using the ELISA technique. Error bars indicate standard deviation. The data are averages from three independent experiments. Statistical significance of results obtained with spores of the analyzed recombinant strains was assessed against data obtained with spores of the 168 wild-type strain, ${ }^{*} p<0.05,{ }^{* *} p<0.01$, ${ }^{* * *} p<0.001$.

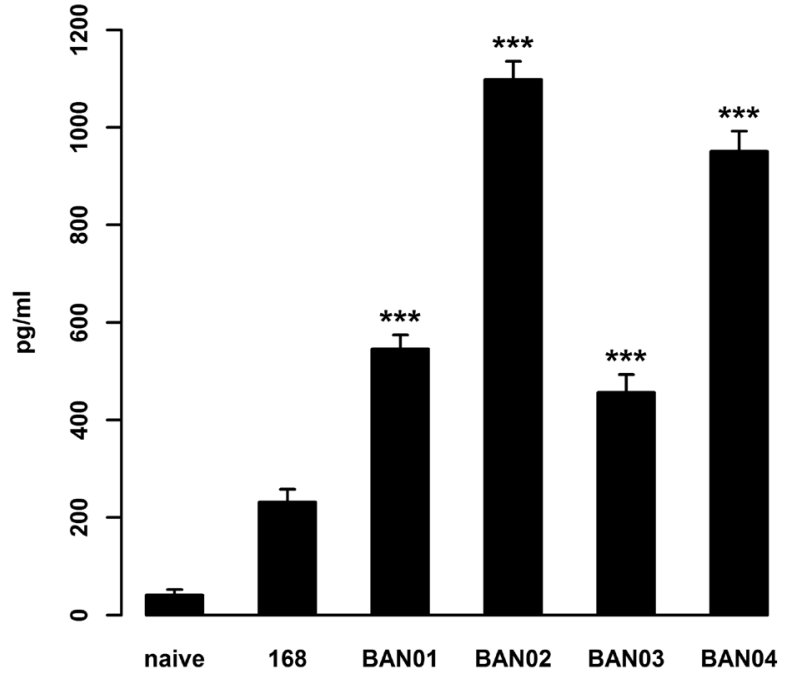

Figure 4. Activation of JAWSII dendritic cells by recombinant spores as assessed by measurement of released IL-12.

The JAWSII cells were treated for $24 \mathrm{~h}$ with spores of strains indicated at the horizontal axis, and the amount of released IL-12 was measured by using the ELISA technique. Error bars indicate standard deviation. The data are averages from three independent experiments. Statistical significance of results obtained with spores of the analyzed recombinant strains was assessed against data obtained with spores of the 168 wild-type strain, ${ }^{* * *} p<0.001$.

\section{Immune response to recombinant spores}

To check how the choice of anchoring protein influences interaction of the recombinant spores with the immune system, we performed mucosal immunization of mice with all variants of the FliD-presenting spores. Since results of our previous research indicated that the recombinant spores did not elicit immune response in mice upon oral immunization without the use of appropriate adjuvants (Hinc et al., 2014; Stasiłojć et al., 2015), we decided to administrate spores by the intranasal route, which was shown to be compatible with such antigen delivery systems (Huang et al., 2010; Isticato \& Ricca, 2014). We were not able to detect a statistically significant increase in levels of FliD-specific antibodies in sera, lungs or gastrointestinal tracts of immunized animals (data not shown). On the other hand, splenocytes isolated from mice immunized with spores produced by the BAN02 strain (CotC-FliD) secreted statistically significant levels of IFN- $\gamma$ and IL-17A (Fig. 5) when compared to the naïve group and the control group immunized with empty spores of the 168 strain. We also observed a statistically insignificant elevation of IL-17A production in mice immunized with spores produced by the BAN03 (CotG-FliD) and BAN04 (CotZ-FliD) strains. No changes in the IL-4 production were observed for all groups of the immunized animals.

\section{DISCUSSION}

One of the major and yet unanswered questions regarding the use of recombinant $B$. subtilis spores for display of heterologous proteins is how the choice of the anchoring coat protein influences the efficiency of passenger protein presentation. In terms of application of $B$. subtilis spores as vehicles of antigens in vaccines, this question can be expressed in other words: how the 
IL-4

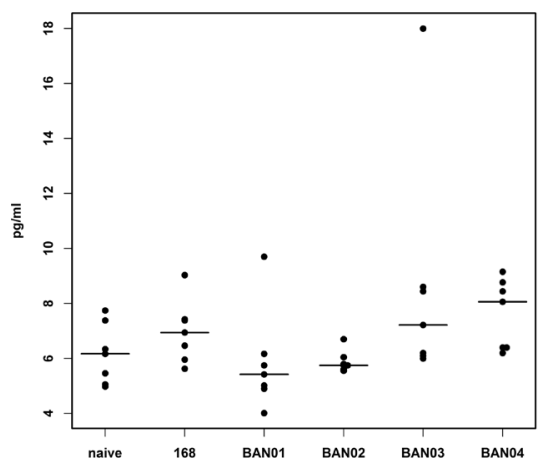

IFN

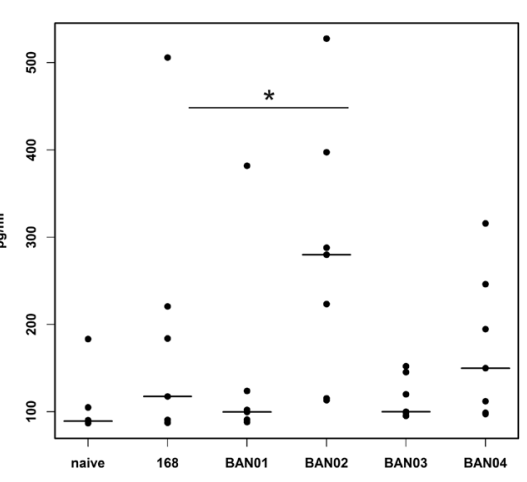

IL-17A

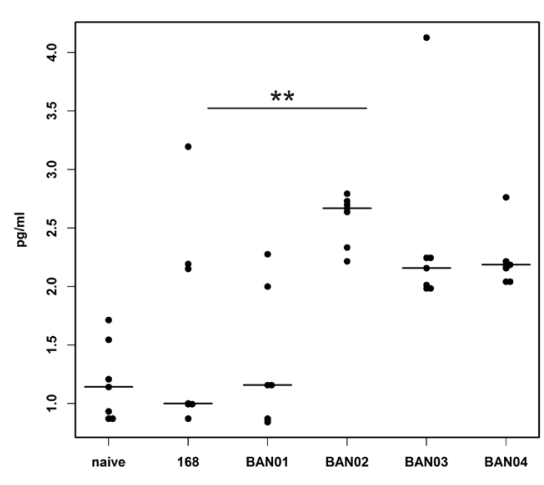

Figure 5. Characterization of the immune response.

Mice (groups of $n=7$ ) were immunized intranasally with spores of the wild-type strain (168) or recombinant strains displaying fusion proteins CotB-FliD (BAN01), CotC-FliD (BAN02), CotG-FliD (BAN03) or CotZ-FliD (BAN04). Levels of cytokines (IFN- $\gamma$, IL-4, IL-17A) secreted by sensitized splenocytes isolated from the immunized animals were assessed by the ELISA technique upon stimulation of cells with purified FliD protein. Bars represent median values. Statistical significance of results obtained with spores of the analyzed recombinant strains was assessed against data obtained with spores of the 168 wild-type strain, ${ }^{*} p<0.05,{ }^{* *} p<0.01$

choice of the anchoring protein changes the interaction of recombinant spores with the immune system.

The difficulty in solving this problem already starts with the anchoring protein itself. Currently, there are no efficient methods enabling direct quantitative analysis of the spore coat proteins. This results from the spore coat properties and structure, where a number of proteins is insoluble and cross-linked (Abhyankar et al., 2014). This has a direct impact on the analysis of fusion proteins extracted from the coats of recombinant spores. The spore coat is very complex and only some of its components have been localized in its structure (Imamura et al., 2010). Intuitively, such information about anchoring proteins should give at least a rough estimation of localization of a fusion protein in the spore coat. However, the results obtained by different research groups, including ours, do not support this assumption, because fusions that were supposed to be displayed with good efficiency sometimes may be barely detected on the spore surface (Hinc et al., 2010).

We made use of a set of recombinant B. subtilis spores displaying a fragment of the FliD protein from C. difficle (Negri et al., 2013) to investigate the interaction of these spores with the innate immune cells. The most efficient FliD exposition was previously observed for spores of the BAN03 (CotG-FliD) strain (Negri et al., 2013). This was not surprising, because the CotG protein, along with CotC and CotD, is known to constitute about $50 \%$ of the soluble spore proteins (Isticato et al., 2004). Moreover, localization of CotG in the spore coat is supposed to encompass the outer coat and partially the crust (McKenney et al., 2010). These facts suggest that spores of the BAN03 strain are likely to exhibit the strongest interaction with cells of the innate immunity system. The results obtained in the study presented here, did not line up with this assumption, since the highest uptake by both, the macrophages and dendritic cells was observed for the BAN01 spores which display FliD in fusion with CotB (Fig. 2). Neither CotB was ever shown to be the most abundant spore coat protein, nor the amount of the CotB-FliD fusion protein extracted from the coat of recombinant spores was found to be the highest (Negri et al., 2013). Ceragioly and coworkers (2009) have shown that recombinant spores presenting tetanus toxin fragment $\mathrm{C}$ (TTFC) in fusion with the CotB protein and the heat-labile toxin of $E$. coli in fusion with CotC protein were similarly internalized by the human macrophages in vitro (Ceragioli et al., 2009). It is worth noting that in case of that study, proteins other than FliD were presented on the surface of the B. subtilis strain PY79 spores, which are not the same as the 168 stain used in our experiments, and moreover the phagocytosis assay was conducted with a human macrophage cell line. Also, observation of different efficiency of uptake of the FliD-presenting spores was not reflected in activation of the phagocytosing cells. Interestingly, the most efficient activation of either type of cells was observed for different recombinant spores, namely BAN02 (CotC-FliD) for both, the J774 (Fig. 3) and JAWSII cells (Fig. 4). These results suggest that the activation of phagocytic activity, as well as the stimulation of cytokine production may depend on different receptors or signaling pathways in the investigated cells. The in vitro observations regarding spores of the BAN02 (CotC-FliD) strain found confirmation in the in vivo experiments, where we observed the highest production of IFN- $\gamma$ and IL-17A in case of mice immunized with this variant of spores (Fig. 5). The observed profile of cytokine secretion suggested polarization of the immune response towards Th1 and Th17. The lack of increase in the IL-4 production, a hallmark cytokine of the humoral immune response, was also reflected in the lack of statistically significant levels of antibodies detected in the immunized animals. It is worth to mention that the immune responses to different recombinant spores were not uniform, which reflected variability in the response of individual animals within immunized groups. The outliers in the recorded data caused non-normal distribution of these results.

The obvious question arises about the nature of interaction of the FliD protein with cells of the innate immune system. Unfortunately, up to date there are no studies that would have explored this subject. The only direct indication for FliD interaction with the immune system is that sera of $C$. difficile infected patients contain high titers of the anti-FliD antibodies (SánchezHurtado et al., 2008). On the other hand, the B. subtilis spores were shown to interact with the innate immune system leading to activation of macrophages (Kosaka et al., 1998) and dendritic cells (Liang et al., 2013). The nature of this interaction was proposed to be via Tolllike receptors (TLRs), although no specific TLR could be indicated as responsible for activation of these cells 
(Huang et al., 2008). In our experiments, both types of cells were activated by spores produced by the wild-type strain. Moreover, all recombinant spores used in this study increased production of cytokines by the J774 cells and JAWSII cells, clearly suggesting that the displayed fusion of the FliD fragment with spore coat proteins is able to activate these cells. Therefore, we could use this set of recombinant spores as a model for spore display of antigens and test how the selection of anchoring proteins influences the interaction with the immune system. Apparently, this interaction is complex and varies between different types of cells of the innate immunity and has a direct impact on interactions with the adaptive immunity. Most probably, this difference lies in the nature of the displayed fusion protein and seems to be less dependent on its abundance or spore surface exposition.

\section{Conflict of interest}

All authors declare no financial or personal relationships with other people or organizations that could inappropriately influence or bias their work.

\section{Acknowledgements of funding}

This research was supported by the National Centre for Research and Development LIDER Programme (LIDER/14/21/L-2/10/NCBiR/2011) and grant no R12 014310.

\section{REFERENCES}

Abhyankar W, de Koning LJ, Brul S, de Koster CG (2014) Spore proteomics: the past, present and the future. FEMS Microbiol Lett 358: 137-144. http://dx.doi.org/10.1111/1574-6968.12568

Anagnostopoulos C, Crawford IP (1961) Transformation studies on the linkage of markers in the tryptophan pathway in Bacillus subtilis. Proc Natl Acad Sci U S A 47: 378-390

Ceragioli M, Cangiano G, Esin S, Ghelardi E, Ricca E, Senesi S (2009) Phagocytosis, germination and killing of Bacillus subtilis spores presenting heterologous antigens in human macrophages. Microbiology 155: 338-346. http://dx.doi.org/10.1099/mic.0.022939-0

Cutting SM (2011) Bacillus probiotics. Food Microbiol 28: 214-220. http://dx.doi.org/10.1016/j.fm.2010.03.007

Duc le H, Hong HA, Fairweather N, Ricca E, Cutting SM (2003) Bacterial spores as vaccine vehicles. Infect Immun 71: 2810-2318

Duc LH, Hong HA, Uyen NQ, Cutting SM (2004) Intracellular fate and immunogenicity of $B$ subtilis spores. Vaccine. 22: 1873-1885

Fakhry S, Sorrentini I, Ricca E, De Felice M, Baccigalupi L (2008) Characterization of spore forming Bacilli isolated from the human gastrointestinal tract. J Appl Microbiol 105: 2178-2186. http://dx.doi. org/10.1111/j.1365-2672.2008.03934.x

Hinc K, Isticato R, Dembek M, Karczewska J, Iwanicki A, PeszyńskaSularz G, De Felice M, Obuchowski M, Ricca E (2010) Expression and display of UreA of Helicobacter acinonychis on the surface of Bacillus subtilis spores. Microb Cell Fact 9: 2. http://dx.doi. org/10.1186/1475-2859-9-2

Hinc K, Iwanicki A, Obuchowski M (2013) New stable anchor protein and peptide linker suitable for successful spore surface display in B subtilis. Microb Cell Fact 12: 22. http://dx.doi.org/10.1186/14752859-12-22

Hinc K, Stasiłojć M, Piątek I, Peszyńska-Sularz G, Isticato R, Ricca E, Obuchowski M, Iwanicki A (2014) Mucosal adjuvant activity of IL-2 presenting spores of Bacillus subtilis in a murine model of Helicobacter pylori vaccination. PLoS One 9: e95187. http://dx.doi. org/10.1371/journal.pone.0095187

Hoang TH, Hong HA, Clark GC, Titball RW, Cutting SM (2008) Recombinant Bacillus subtilis expressing the Clostridium perfringens alpha toxoid is a candidate orally delivered vaccine against necrotic enteritis. Infect Immun 76: 5257-5265. http://dx.doi.org/10.1128/ IAI.00686-08

Hong HA, To E, Fakhry S, Baccigalupi L, Ricca E, Cutting SM (2009) Defining the natural habitat of Bacillus spore-formers. Res Microbiol. 160: 375-379. http://dx.doi.org/10.1016/j.resmic.2009.06.006

Huang JM, La Ragione RM, Nunez A, Cutting SM (2008) Immunostimulatory activity of Bacillus spores. FEMS Immunol Med Microbiol 53: 195-203. http://dx.doi.org/10.1111/j.1574-695X.2008.00415.x
Huang JM, Hong HA, Van Tong H, Hoang TH, Brisson A, Cutting SM (2010) Mucosal delivery of antigens using adsorption to bacterial spores. Vaccine. 28: 1021-1030. http://dx.doi.org/10.1016/j.vaccine.2009.10.127

Imamura D, Kuwana R, Takamatsu H, Watabe K (2010) Localization of proteins to different layers and regions of Bacillus subtilis spore coats. J Bacteriol 192: 518-524. http://dx.doi.org/10.1128/JB.0110309

Isticato R, Cangiano G, Tran HT, Ciabattini A, Medaglini D, Oggioni MR, De Felice M, Pozzi G, Ricca E (2001) Surface display of recombinant proteins on Bacillus subtilis spores. J Bacteriol 183: 6294 6301

Isticato R, Esposito G, Zilhão R, Nolasco S, Cangiano G, De Felice M, Henriques AO, Ricca E (2004) Assembly of multiple CotC forms into the Bacillus subtilis spore coat. I Bacteriol 186: 1129-1135

Isticato R, Sirec T, Treppiccione L, Maurano F, De Felice M, Rossi M, Ricca E (2013) Non-recombinant display of the B subunit of the heat labile toxin of Escherichia coli on wild type and mutant spores of Bacillus subtilis. Microb Cell Fact. 12: 98. http://dx.doi. org/10.1186/1475-2859-12-98

Isticato R, Ricca E (2014) Spore surface display. Microbiol Spectr 5: TBS0011-2012. http://dx.doi.org/10.1128/microbiolspec.TBS-00112012

Iwanicki A, Piątek I, Stasiłojć M, Grela A, Lęga T, Obuchowski M, Hinc K (2014) A system of vectors for Bacillus subtilis spore surface display. Microb Cell Fact 13: 30. http://dx.doi.org/10.1186/14752859-13-30

Kosaka T, Maeda T, Nakada Y, Yukawa M, Tanaka S (1998) Effect of Bacillus subtilis spore administration on activation of macrophages and natural killer cells in mice. Vet Microbiol 60: 215-225

Liang J, Fu J, Kang H, Lin J, Yu Q, Yang Q (2013) The stimulatory effect of TLRs ligands on maturation of chicken bone marrow-derived dendritic cells. Vet Immunol Immunopathol 155: 205-210. http:// dx.doi.org/10.1016/j.vetimm.2013.06.014

McKenney PT, Driks A, Eskandarian HA, Grabowski P, Guberman J, Wang KH, Gitai Z, Eichenberger P (2010) A distance-weighted interaction map reveals a previously uncharacterized layer of the Bacillus subtilis spore coat. Curr Biol 20: 934-938. http://dx.doi. org/10.1016/j.cub.2010.03.060

McKenney PT, Driks A, Eichenberger P (2013) The Bacillus subtilis endospore: assembly and functions of the multilayered coat. Nat Rev Microbiol 11: 33-44. http://dx.doi.org/10.1038/nrmicro2921

Negri A, Potocki W, Iwanicki A, Obuchowski M, Hinc K (2013) Expression and display of Clostridium difficile protein FliD on the surface of Bacillus subtilis spores. J Med Microbiol 62: 1379-1385. http:// dx.doi.org/10.1099/jmm.0.057372-0

Nicholson WL, Setlow P (1990) Sporulation, germination and outgrowth. In Molecular Biological Methods for Bacillus Harwood C, Cutting S eds, pp 391-450. John Wiley and Sons

Nicholson WL (2002) Roles of Bacillus endospores in the environment. Cell Mol Life Sci 59: 410-416

Péchiné S, Gleizes A, Janoir C, Gorges-Kergot R, Barc MC, Delmée M, Collignon A (2005) Immunological properties of surface proteins of Clostridium difficile. J Med Microbiol 54: 193-196

Permpoonpattana P, Hong HA, Phetcharaburanin J, Huang JM, Cook J, Fairweather NF, Cutting SM (2011) Immunization with Bacillus spores expressing toxin A peptide repeats protects against infection with Clostridium difficile strains producing toxins A and B. Infect Immun 79: 2295-2302. http://dx.doi.org/10.1128/IAI.00130-11

Ricca E, Baccigalupi L, Cangiano G, De Felice M, Isticato R (2014) Mucosal vaccine delivery by non-recombinant spores of Bacillus subtilis. Microb Cell Fact 13: 115. http://dx.doi.org/10.1186/s12934-0140115-2

Sánchez-Hurtado K, Corretge M, Mutlu E, McIlhagger R, Starr JM, Poxton IR (2008) Systemic antibody response to Clostridium difficile in colonized patients with and without symptoms and matched controls. J Med Microbiol 57: 717-724. http://dx.doi.org/10.1099/ jmm.0.47713-0

Stasiłojć M, Hinc K, Peszyńska-Sularz G, Obuchowski M, Iwanicki A (2015) Recombinant Bacillus subtilis Spores Elicit Th1/Th17polarized immune response in a murine model of Helicobacter pylori vaccination. Mol Biotechnol 57: 685-691. http://dx.doi.org/10.1007/ s12033-015-9859-0

Tasteyre A, Barc MC, Collignon A, Boureau H, Karjalainen T (2001) Role of FliC and FliD flagellar proteins of Clostridium difficile in adherence and gut colonization. Infect Immun 69: 7937-7940

Valdez A, Yepiz-Plascencia G, Ricca E, Olmos J (2014) First Litopenaeus vannamei WSSV $100 \%$ oral vaccination protection using CotC::Vp26 fusion protein displayed on Bacillus subtilis spores surface. J Appl Microbiol 117: 347-357. http://dx.doi.org/10.1111/jam.12550 